\title{
A CONSERVATIVE APPROACH TO MANAGE ACUTE PULPITIS USING BIODENTINE A TWO YEARS' STUDY
}

\author{
Hala Fares
}

\begin{abstract}
The conservative approach is now proving to be a more reliable pulp therapy. The aim of this study is to assess the role of Biodentine as a conservative therapy in managing cases of acute pulpitis. Twenty permanent teeth belonging to healthy university students were included in this study. The treated teeth were re-evaluated after six weeks, six months and two years, clinically and radiographically. For seventeen cases, clinical and radiographic examination revealed appropriate function, absence of signs and symptoms and normal periodontium at all time periods.
\end{abstract}

Keywords: Biodentine- acute pulpitis- conservative pulp therapy

\section{INTRODUCTION}

The conservative approach is currently proving to be a more reliable pulp therapy. Pulp healing is a complex molecular and cellular process. The sequence of events in pulpal healing is similar to a connective tissue injury ${ }^{(1)}$. Schroder describes the first stage to involve vascular and inflammatory cell migration, proliferation and adhesion to control and eliminate the irritant. In the second stage repair occurs with migration, proliferation and adhesion of mesenchymal and dental pulp stem cells. Regeneration of the dentin- pulp complex after severe injury involves dental pulp stem cells differentiation into secondary or replacement odontoblasts and subsequent dentinogenesis ${ }^{(1)}$.
An ideal material for pulp therapy should have the ability to stimulate and modulate the healing process for a complete dentin- pulp complex recovery. Understanding these mechanisms provides important implications for the development of new therapeutic strategies in dental pulp therapy.

Biodentine (Septodont, Saint Maur des Fossés, France) is a new calcium silicate-based restorative cement with dentin-like mechanical properties, which can be used as a dentin substitute on crowns and roots similar to how MTA is used ${ }^{(3,4,5-9)}$. It has a positive effect on vital pulp cells and stimulates tertiary dentin formation ${ }^{(3,4,9,10)}$.

In direct contact with vital pulp tissue, it also promotes formation of reparative $\operatorname{dentin}^{(3,9)}$.

* Lecturer, Department of Operative and Cosmetic Dentistry, Faculty of Oral and Dental Surgery, Misr University for Science and Technology. Egypt. 
Biodentine consists of a powder and liquid. The powder mainly contains tricalcium and dicalcium silicate $\left(3 \mathrm{CaO} \mathrm{SiO}\right.$ and $\left.2 \mathrm{CaO} \mathrm{SiO}_{2}\right)$, the principal component of Portland cement, as well as calcium carbonate $\left(\mathrm{CaCO}_{3}\right)$. zirconium dioxide $\left(\mathrm{ZrO}_{2}\right)$ serves as contrast medium. The liquid consists of calcium chloride $\left(\mathrm{CaCl}_{2} \cdot 2 \mathrm{H}_{2} \mathrm{O}\right)$, which is used as a setting accelerator and water-reducing agent in aqueous solution with an admixture of polycarboxylate (a superplasticizing agent) ${ }^{(3,9)}$. The consistency of Biodentine is similar to that of phosphate cement. The material can be applied directly in the restorative cavity with a spatula as a bulk dentin substitute without any conditioning treatment ${ }^{(3,5-9)}$.

Recent researches recommend adult pulpotomy as a reliable and conservative pulp therapy ${ }^{(11-18)}$.

Traditional endo has been described to have other additional drawbacks, e.g. the discomfort related to the anesthesia, rubber dams, especially with long periods with the mouth open, retreatments, postop sensitivity, blowups, blocked canals, separated files, apicoectomies, hypochorite leaks, ledges, excessive biofilms, lateral canals, anastomoses, deltas, over fills, under fills, cracks, perforations and micro surgery ${ }^{(11,19-21)}$.

This study with a two years follow up clinically and radiographically was conducted to assess the role of Biodentine as a conservative therapy in managing cases of acute pulpitis.

\section{METHODS AND MATERIALS}

Twenty permanent molars and premolars belonging to twenty adult male and female university students (ten males and ten females), were included in this study. Regarding all subjects, there were no medical contraindications for dental treatment. The patients aged twenty to twenty five years old. All selected patients had undergone thorough clinical examination to make sure they had good oral hygiene. These patients came to us and were seeking a conservative pulp therapy rather than regular endodontic treatment. All of them suffered moderate to severe pain as a result of irreversible pulpitis. Teeth were examined to ensure pulp vitality. Also an informed consent from each patient was obtained. The reason that we chose our university students was to facilitate recall and follow up. Anaesthesia was performed followed by proper isolation using a rubber dam. All caries was removed using high speed burs with thorough irrigation. The pulp chamber was then opened and deeper caries, in addition to; the inflamed pulp tissue was removed to orifice level using a large high speed round bur and appropriate water cooling. Bleeding was made to stop using sterile normal saline irrigation in addition to sterile cotton pellets. Biodentine was applied according to the manufacturer's instruction. All cavity walls were, then, conditioned and bonding performed using Single bond $3 \mathrm{M}^{\mathrm{TM}} \mathrm{ESPE}^{\mathrm{TM}}$ (table 1), in order to strengthen the remaining tooth structure. Finally a resin composite restorative material (Filtek Z 250, $3 \mathrm{M}^{\mathrm{TM}} \mathrm{ESPE}^{\mathrm{TM}}$ ) was used for restoration. The treated teeth were re-evaluated after six weeks, six months and two years; clinically for signs and symptoms, and radiographically to assess the periodontium apparatus.

\section{RESULTS}

\section{Clinical examination}

At all time periods (six weeks, six months and two years), seventeen of the treated teeth demonstrated appropriate function. No signs and symptoms as pain, swelling, tenderness, tooth mobility or fistula were present. The remaining three cases failed over three months, six months and two years respectively and needed traditional endodontics.

\section{Radiographic examination}

At all time periods (six weeks, six months and two years), seventeen of the treated teeth demonstrated normal periodontium and absence of intercanal or perpiapical pathology. The above mentioned three cases that failed clinically also revealed radiographic changes indicative of failure. 
TABLE (1) Materials, components, batch numbers and manufactures

\begin{tabular}{|c|c|c|c|}
\hline Material & Components & Batch number & Manufacturers \\
\hline Biodentine & $\begin{array}{l}\text { Powder } \\
\text {-Tricalcium Silicate. } \\
\text {-Dicalcium Silicate. } \\
\text {-Calcium Carbonate. } \\
\text {-Oxide filler. } \\
\text {-Iron Oxide shade. } \\
\text {-Zirconium Oxide. } \\
\text { Liquid } \\
\text {-Calcium chloride (accelerator). } \\
\text { Hydrosoluble polymer. }\end{array}$ & B02282 & Septodont \\
\hline $\begin{array}{l}3 \mathrm{M}^{\mathrm{TM}} \mathrm{ESPE}^{\mathrm{TM}} \\
\text { Single Bond }\end{array}$ & Dental adhesive system & N628066 & $\begin{array}{c}\text { 3M ESPE Dental Products } \\
\text { St Paul, MN, USA }\end{array}$ \\
\hline $\begin{array}{c}3 \text { M Filtek }{ }^{\mathrm{TM}} \mathrm{Z} \\
250 \mathrm{XT}\end{array}$ & Nanohybrid composite & N535294 & $\begin{array}{c}\text { 3M ESPE Dental Products } \\
\text { St Paul, MN, USA }\end{array}$ \\
\hline
\end{tabular}

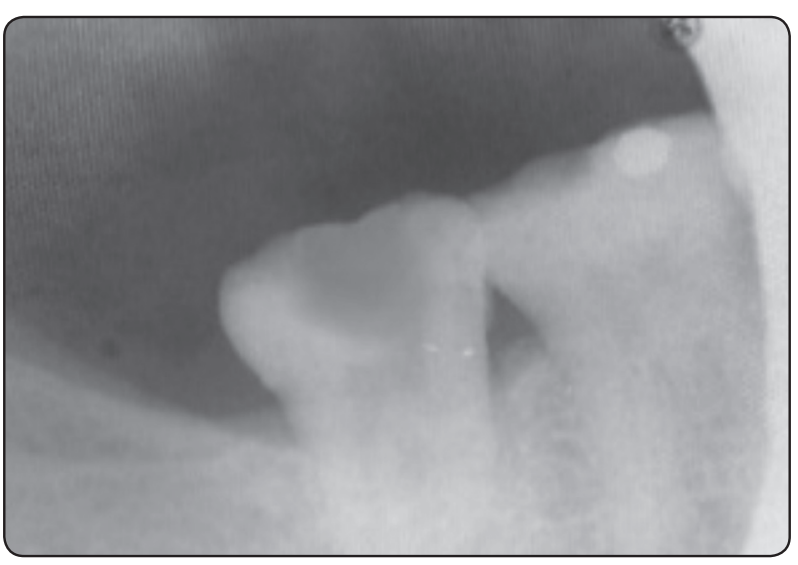

Fig. (1): A radiograph of a tooth suffering acute pulpitis.

\section{Statistical analysis}

Success data (Qualitative data) were presented as frequencies (n) and percentages (\%). Cochran's Q test was used to compare between success and failure through the follow-up periods.

The significance level was set at $\mathrm{P} \leq 0.05$. Statistical analysis was performed with IBM ${ }^{\circledR}$ SPSS® Statistics Version 20 for Windows.

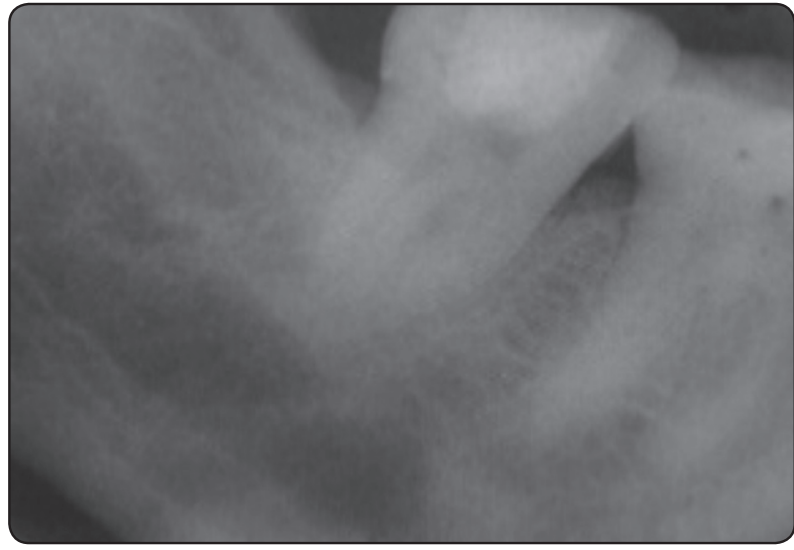

Fig. (2): A radiograph of the same tooth after performing adult pulpotomy using Biodentine (after two years).

\section{RESULTS}

At 6 weeks as well as 6 months follow-up periods; all cases (100.0\%) showed success. After 2 years, 17 cases $(85.0 \%)$ showed success while only 3 cases $(15.0 \%)$ showed failure. There was no statistically significant change in success rate through the follow-up periods. 
TABLE (2) Descriptive statistics and results of Cochran's Q test for the success and failure through the follow-up periods

\begin{tabular}{|c|c|c|c|c|}
\hline Outcome & 6 weeks & 6 months & 2 years & \multirow{2}{*}{ P-value } \\
\hline & $\mathrm{n},(\%)$ & $\mathrm{n},(\%)$ & $\mathrm{n},(\%)$ & \\
\hline $\begin{array}{c}\text { Success } \\
\text { Failure }\end{array}$ & $\begin{array}{c}20(100.0) \\
0(0.0)\end{array}$ & $\begin{array}{c}20(100.0) \\
0(0.0)\end{array}$ & $\begin{array}{c}17(85.0) \\
3(15.0)\end{array}$ & \multirow{2}{*}{0.0501} \\
\hline
\end{tabular}

\section{*: Significant at $P \leq 0.05$}

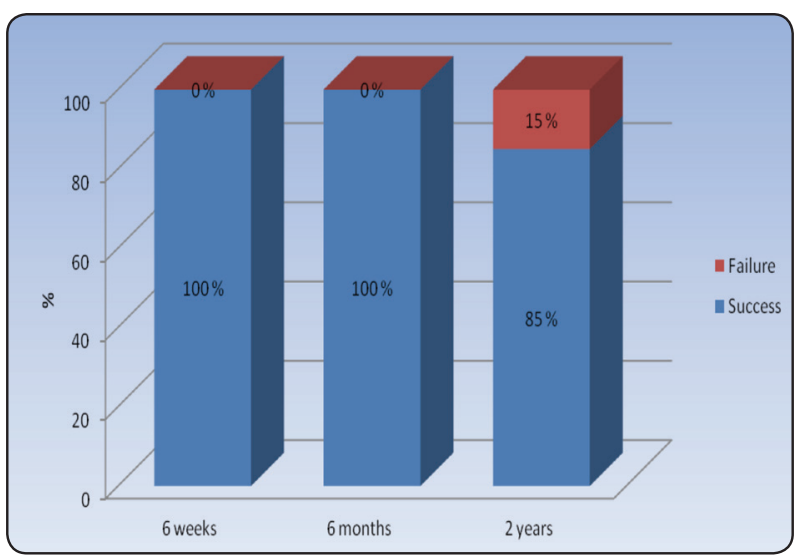

Fig. (3) Stacked bar chart representing percentages of success and failure through the follow-up periods

\section{DISCUSSION}

It is inevitable nowadays that conservative therapeutic approaches are the methods of choice regarding all medical fields. In light of conservative dentistry, traditional endodontic treatment is a comparatively invasive procedure. The concept that traditional endodontia is the most reliable treatment is to date changing in favor of other conservative approaches ${ }^{(11-18)}$. This goes in accordance with our study.

Traditional endo has been described to have other additional drawbacks, e.g. the discomfort related to the anesthesia, rubber dams, especially with long periods with the mouth open, retreatments, post-op sensitivity, blowups, blocked canals, separated files, apicoectomies, hypochorite leaks, ledges, excessive biofilms, lateral canals, anastomoses, deltas, over fills, under fills, cracks, perforations and micro surgery ${ }^{(11,19-21)}$.

In this study males and females were included in order to rule out gender as a factor. All subjects were university students to facilitate recall and follow up. Medical examination was required to rule out any medical contraindication for dental treatment. Dental examination was performed to ensure good oral hygiene and pulp vitality. In addition to the above mentioned precautions our success in this study is primarily attributed to the Biodentine material itself. Handling characteristics are important when considering any material for clinical use. In this study, because of the mechanical properties of Biodentine, this material received good rates for material handling and performance after restoration placement ${ }^{(2-9)}$. Laurent et $\mathrm{al}^{(3)}$, showed that the particles of Biodentine were entrapped in the newly formed foci, and mineralization appeared as osteodentin. This means that the material's physicochemical properties could promote the mineralization process. Stimulation of cell proliferation and differentiation might be related to the tricalcium silicate itself, which is one of the main components of Biodentin, and the presence of both calcium and silicone ions ${ }^{(2-4,4-810)}$.

Tran et $\mathrm{al}^{(9)}$ reported that these reparative structures that were induced by Biodentine, were homogenous and in continuity with primary dentin.

Studies report that pulp response is linked to bacterial microleakage ${ }^{(22-28)}$. It was noted that bacteria stimulate pulpal inflammatory activity ${ }^{(29)}$. Many authors have suggested that pulpal survival is not so much a function of an agent's potential bioactivity but its capacity to protect the pulp from bacterial leakage ${ }^{(24,30-34)}$. It was reported that biodentin have excellent sealing properties ${ }^{(2,5,6)}$. Thus the fact that Biodentine protects the pulp from bacterial leakage is another contributing factor in the success of pulp 
therapy. Wound healing processes are divided into three distinct phases, first is the inflammatory and fibrogenic phase, second is the regenerative phase, and third is a remodeling phase ${ }^{(35)}$. Among these phases cell proliferation, migration and adhesion are essential processes in tissue regeneration. Progenitor cells give rise to a new generation of odontoblastslike cells re- constituting the lost continuum at the pulp- dentin border ${ }^{(1,36,37)}$.Cell migration and adhesion are necessary for homeostatic tissue maintenance and the regeneration of injured organs and tissues ${ }^{(1,38)}$. Cells must migrate and adhere to sites where they are required to function, otherwise the regeneration and development of functional organs and tissues would be impossible ${ }^{(1,39)}$. A special population of cells called dental pulp stem cells (DPSCs) $)^{(40)}$, odontoblasts like cells ${ }^{(41)}$ are known to respond to tooth injury by proliferating, migrating, differentiating and adhesion to replace lost odontoblasts leading to the synthesis and secretion of tertiary dentin ${ }^{(1,42)}$. Results showed that Biodentin produced a significantly increased migration and adhesion abilities of hDPSCs. It is suggested that a possible role for Biodentine might be through up-regulation of the mRNA expression of chemokines and adhesion moleculesand a definite effect of Biodentine on these cellular processes ${ }^{(1)}$. So, in our opinion the fact that Biodentine increases the migration and adhesion of $\mathrm{h}$ DPSCs further potentiates its role in pulpal therapy. Also, it was further hypothesized that Biodentin caused a local increase in the concentration of a certain growth factor (TGF- $\beta 1$ ) which contribute to odontoblasts like cells' differentiation and mineralization ${ }^{(43.44)}$. It was suggested that TGF- $\beta 1$ acted as a modulator of reparative processes in various tissues and that in the dental pulp, TGF- $\beta 1$ promoted progenitor cell migration $^{(45)}$ and odontoblast differentiation ${ }^{(46)}$.

Three cases failed and that in our opinion is attributed probably to the extension of damage which might have reached beyond the pulp chamber to pulp of the root canals.

\section{CONCLUSION}

Biodentin has proven to be successful in conservative pulp therapy due to its capability of inducing proliferation, migration and adhesion of human pulp stem cells.

\section{REFERENCES}

1- Luo Z, Li D, Kohli R, Yu Q, Kim S and He W. Effect of Biodentine on the proliferation, migration and adhesion of human dental pulp stem cells. J Dent 2014; 42: 490-497.

2- Nocircka A, Lipski M, Barafiniuk M, Tutak SK, Lichota D, Kosierkiewicz W and Radlinska BJ. Response of human dental pulp capped with Biodentine and mineral trioxide aggregate. J Endod 2013; 39: 743-747.

3- Laurent P, Camps J, About I. BiodentineTM induces TGFb1 release from human pulp cells and early dental pulp mineralization. IntEndod J 2012;45: 439- 448.

4- Zanini M, Sautier JM, Berdal A, Simon S. Biodentine induces immortalized murine pulp cell differentiation into odontoblast-like cells and stimulates biomineralization. J Endod 2012;38: 1220-1226.

5- Koubi G, Colon P, Franquin JC, et al. Clinical evaluation of the performance and safety of a new dentine substitute, Biodentine, in the restoration of posterior teeth: a prospective study. Clin Oral Investig 2013;17: 243- 249.

6- Raskin A, Eschrich G, Dejou J, About I. In vitro microleakage of Biodentine as a dentin substitute compared to Fuji II LC in cervical lining restorations. J Adhes Dent 2012;14: 535- 542 .

7- Koubi S, Elmerini H, Koubi G, et al. Quantitative evaluation by glucose diffusion of microleakage in aged calcium silicate-based open-sandwich restorations. Int J Dent 2012;2012:1058-63. http://dx.doi. org/10.1155/2012/105863 [Epub 2011 Dec 12].

8- Laurent P, Camps J, De Meo M, et al. Induction of specific cell responses to a $\mathrm{Ca} 3 \mathrm{SiO} 5$ - based posterior restorative material. Dent Mater 2008;24: 1486-1494.

9- Tran XV, Gorin C, Willig C, et al. Effect of a calciumsilicate-based restorative cement on pulp repair. J Dent Res 2012;91: 1166-1171.

10- Peng W, Liu W, Zhai W, et al. Effect of tricalcium silicate on the proliferation and odontogenicdifferentiation of human dental pulp cells. J Endod 2011; 37: 1240- 1246. 
11- Ellis J. Neiburger. Glidewell laboratories 2013; Vol. 7 (1).

12- Cohen BI, Pagnillo MK, Musikant BL, Deutsch AS. Formaldehyde evaluation from endodontic materials. Oral Health 1998; 88 (12): 37-9.

13- Asgary S, Ehsani S. Permanent molar pulpotomy with a new endodontic cement: case series. J Conserv Dent 2009; 12 (1): 31-6.

14- Asgary S, Eghbal MJ. A clinical study of pulpotomy VS root canal treatment of mature molars. J Dent Res. 89 (10): 1080-5. Epub, 2010.

15- Aguilar, P, Linsuwanont P. Vital pulp therapy in vital permanent teeth with cariously exposed pulp: a systematic review. J Endod 2011; 37 (5): 581-7 Epub.

16- Bjorndal L Treatment of deep caries lesions in adults: randomized clinical trials comparing stepwise vs direct complete excavation, and direct pulp capping vs partial pulpotomy. Eur Science 2010; 118 (3): 290-7.

17- Eghbal MJ, Asgary S, Baglue RA, Parirokh M, Ghoddusi J. MTA pulpotomy of human permanent molars with irreversible pulpitis. Aust EndodJ 2009; 35 (1): 4-8.

18- Caliskan MK. Pulpotomy of carious vital teeth with periapical involment. Int Endod 1995; 28 (3) 172-6.

19- Hugh CL, Walton RE, Facer SR Evaluation of intracanal sealer distribution with 5 different obturation techniques. Quintessence Int 2005; 36 (9): 721-9.

20- Lin LM, Rosenberg PA, Lin J. Do procedural errors cause endodontic treatment failure? J Am Dent Assoc 2005; 136 (2): $187-93$.

21- Hollanda AC, Estrela CR, Decurcio Dde, A, Silva JA, Estrela C. Sealing ability of three commercial resin-based endodontic sealers. Gen Dent 2009; 57 (4): 368-73.

22- Iwamoto $\mathrm{CE}$, Adachi E, Pameijer $\mathrm{CH}$, et al. Clinical and histological evaluation of white ProRoot MTA in direct pulp capping. Am J Dent 2006;19:85-90.

23- Aeinehchi M, Eslami B, Ghanbariha M, Saffar AS. Mineral trioxide aggregate (MTA) and calcium hydroxide as pulp-capping agents in human teeth: a preliminary report. IntEndod J 2003;36: 225-231.

24- Asgary S, Eghbal MJ, Parirokh M, et al. A comparative study of histologic response to different pulp capping materials and a novel endodontic cement. Oral Surg Oral Med Oral Pathol Oral RadiolEndod 2008;106: 609- 614.
25- Eskandarizadeh A, Shahpasandzadeh MH, Shahpasandzadeh $\mathrm{M}$, et al. A comparative study on dental pulp response to calcium hydroxide, white and grey mineral trioxide aggregate as pulp capping agents. J Conserv Dent 2011;14: 351- 355 .

26- Faraco IM Jr, Holland R. Response of the pulp of dogs to capping with mineral trioxide aggregate or a calcium hydroxide cement. Dent Traumatol 2001; 17: 163-166.

27- Accorinte ML, Loguercio AD, Reis A, et al. Response of human dental pulp capped with MTA and calcium hydroxide powder. Oper Dent 2008;33: 488- 495.

28- Parirokh M, Torabinejad M. Mineral trioxide aggregate: a comprehensive literatureReview-part I: chemical, physical, and antibacterial properties. J Endod 2010; 36: 16-27.

29- Murray PE, García- Godoy F. the incidence of pulp healing defects with direct capping material. Am J Dent 2006; 19: $171-177$.

30- Cox CF, S€ubay RK, Ostro E, et al. Tunnel defects in dentin bridges: their formation following direct pulp capping. Oper Dent 1996; 21: 4-11.

31- Nair PN, Duncan HF, Pitt Ford TR, Luder HU. Histological, ultrastructural and quantitative investigations on the response of healthy human pulps to experimental capping with mineral trioxide aggregate: a randomized controlled trial. IntEndod J 2008; 41: 128-150.

32- Cox CF, Keall CL, Keall HJ, et al. Biocompatibility of surface-sealed materials against exposed pulps. J Prosthet Dent 1987;57:1-8.

33- Tobias M, Cataldo E, Shiere FR, Clark RE. Pulp reaction to a resin-bonded quartz composite material. J Dent Res 1973;52: 1281- 1286 .

34- Bergenholtz G, Cox CF, Loesche WJ, Syed SA. Bacterial leakage around dental restorations: its effect on the dental pulp. J Oral Pathol 1982;11: 439- 450.

35- Gurtner GC, Werner S, Barrandon Y, Longaker MT. Wound repair and regeneration. Nature 2008;453: 314- 321.

36- Fitzgerald M. Cellular mechanics of dentinal bridge repair using H thymidine. Journal of Dental Research 1979; 58: 2198- 2206.

37- Bjorndal L, Mjor IA. Pulp-dentin biology in restorative dentistry. Part 4: Dental caries - characteristics of lesions and pulpal reactions. Quintessence International 2001;32: 717-736. 
38- Gilbert SF. The morphogenesis of evolutionary developmental biology. International Journal of Developmental Biology 2003;47: 467- 477.

39- Singer AJ, Clark RA. Cutaneous wound healing. New England Journal of Medicine 1999;341: 738- 746.

40- Takeda T, Tezuka Y, Horiuchi M, Hosono K, Iida K, Hatakeyama D, et al. Characterization of dental pulp stem cells of human tooth germs. Journal of Dental Research 2008;87: 676-681.

41- Alliot-Licht B, Bluteau G, Magne D, Lopez-Cazaux S, Lieubeau B, Daculsi G, et al. Dexamethasone stimulates differentiation of odontoblast-like cells in human dental pulp cultures. Cell and Tissue Research 2005; 321: 391- 400 .

42- Qvist V. Pulp reactions in human teeth to tooth colored filling materials. Scandinavian Journal of Dental Research 1975;83: 54- 66 .

43- Smith AJ, Murray PE, Sloan AJ, Matthews JB, Zhao S (2001) Trans-dentinal stimulation of tertiary dentinogenesis. Adva in Dent Res 15, 51- 54.

44- Laurent P, Camps J and About I. Biodentine induces TGF$\beta 1$ release from human pulp cells and early dental pulp mineralization. Int Endod J 2011; 45: 139-448

45- Howard C, Murray PE, Namerow KN (2010) Dental pulp stem cell migration. J of Endod 36, 1963- 1966.

46- Begue-Kirn C, Smith AJ, Ruch JV et al. (1992) Effects of dentin proteins, transforming growth factor beta 1 (TGF beta 1) and bone morphogenetic protein 2 (BMP2) on the differentiation of odontoblast in vitro. The International $\mathrm{J}$ of DeveBiol 36, 491-503. 